\title{
Endemism and migration in the Kochkor Basin? Identification and description of Adcrocuta eximia (Mammalia: Carnivora: Hyaenidae) and c.f. Paramachaerodus (Mammalia: Carnivora: Felidae) fossils at the Miocene locality of Ortok, Kyrgyzstan
}

\author{
Sophie A. Miller, Paul Z. Barrett, Win N.F. McLaughlin, and Samantha S.B. Hopkins
}

\begin{abstract}
Dentition from a Miocene hyaenid and a saber-toothed felid are described from the Chu Formation of Kyrgyzstan. Identified as Adcrocuta eximia (UOMNH F-70508) and c.f. Paramachaerodus (UOMNH F-70509), these represent one of the only formalized descriptions of fossil taxa from the Miocene in Kyrgyzstan. These specimens were recovered from the Ortok locality at the northwestern corner of the Kochkor Basin, the youngest of the known bone-bed localities in the Chu Formation. Using bio- and magnetostratigraphy, the Chu Formation is attributed to the late Miocene to Pliocene, deposited approximately at 8 to $4 \mathrm{Ma}$. The Adcrocuta specimen consists of a partial dentary with condylar and angular processes, one upper, five lower teeth, and the partial root and alveoli of a fifth mandibular tooth. The c.f. Paramachaerodus specimen includes a partial M1, P4, and C1, and exhibits the features of the "scimitar-toothed" machairodontines. Preserved diagnostic characters place the Kyrgyz specimen closest to $P$. ogygia, although with certain features similar to that of $P$. transasiaticus, such as incipient crenulations on the canine. However, the age of the Kyrgyz specimen, approximately $6 \mathrm{Ma}$, is substantially younger than what is known for either of these taxa. We therefore hypothesize this Paramachaerodus specimen could be evidence of an endemic taxon in Kyrgyzstan from earlier migrating Asian species, potentially due to geological uplift with the Tien Shan Mountains. Both these fossils bring new evidence of the ecology and biodiversity of Chu fauna during the Late Miocene/Early Pliocene in Kyrgyzstan.
\end{abstract}

Sophie A. Miller. Department of Anthropology, University of Oregon, Eugene, Oregon 97403, USA; Museum of Natural and Cultural History, University of Oregon, Eugene, Oregon 97403, USA. smiller3@uoregon.edu

Paul Z. Barrett. Department of Earth Sciences, University of Oregon, Eugene, Oregon 97403, USA and

\footnotetext{
Miller, Sophie A., Barrett, Paul Z., McLaughlin, Win N.F., and Hopkins, Samantha S.B. 2020. Endemism and migration in the Kochkor Basin? Identification and description of Adcrocuta eximia (Mammalia: Carnivora: Hyaenidae) and c.f. Paramachaerodus (Mammalia: Carnivora: Felidae) fossils at the Miocene locality of Ortok, Kyrgyzstan. Palaeontologia Electronica, 23(3):a45. https://doi.org/ $10.26879 / 1033$

palaeo-electronica.org/content/2020/3156-ortok-carnivores

Copyright: September 2020 Society of Vertebrate Paleontology.

This is an open access article distributed under the terms of the Creative Commons Attribution License, which permits unrestricted use, distribution, and reproduction in any medium, provided the original author and source are credited. creativecommons.org/licenses/by/4.0
} 
Museum of Natural and Cultural History, University of Oregon, Eugene, Oregon 97403, USA. pbarrett@uoregon.edu

Win N.F. McLaughlin. Department of Geology, Pomona College, 333 N. College Way, Claremont, California 91711, USA.win.mclaughlin@pomona.edu

Samantha S.B. Hopkins. Department of Earth Sciences, University of Oregon, Eugene, Oregon 97403, USA; Clark Honors College, University of Oregon, Eugene, Oregon 97403, USA; Museum of Natural and Cultural History, University of Oregon, Eugene, Oregon 97403, USA. shopkins@uoregon.edu

Keywords: Paramachaerodus; Adcrocuta; Kyrgyzstan; Miocene; Ortok; Endemism

Submission: 22 September 2019. Acceptance: 29 August 2020.

\section{INTRODUCTION}

Historically, Central Asian paleontology has received comparatively less attention, with many researchers settling for assumptions about biogeography due to fossils and reports lost in wars and collection continuity. Therefore, much of the paleontological work in Kyrgyzstan and the surrounding countries requires modern revisions.

Although there are limited faunal lists for the Kochkor Basin of Kyrgyzstan, often published in Russian (see Zhegallo, 1961; Belyaeva and Kurdyukov, 1963; Neimyshev, 1965; Dmitrieva and Nesmejanov, 1982; Vangengeim et al., 1989), these are primarily listings of now synonymised taxa, and do not include formal detailed descriptions of the Neogene vertebrate fauna. For example, a Crocuta eximia (=Adcrocuta eximia, see Werdelin and Solounias, 1991) found $8 \mathrm{~km}$ southwest of the town of Kochkor (Neimyshev, 1965), an Ictitherium c.f. wongi (= Hyaenotherium wongii Zdansky, 1924, see Werdelin and Solounias, 1991), a Hyaena sp., an Adcrocuta sp. at "Ortok" (Zhegallo, 1961), and a 'Hyaenidae' from unknown locality "At-Bashy", among other listed fauna (Belyaeva and Kurdyukov, 1963).

Little attention appears to have been paid to the fauna, and the location or continued existence of much of the vertebrate material is now unknown, as it is not contained in the history museum in Bishkek, the paleontological collection in Almaty Kazakhstan, or in the Russian National collection in Moscow. In the 1960s, two Eocene fossil localities were discovered, Toru Agyr on the Northwest margin of Issyk Kul and Andarak on the southwest Kyrgyz edge of the Fergana Valley. Some of the material was described and published (Belyaeva, 1962; Erfurt et al., 1999), although the location and continued existence of the fossil material from Toru Agyr is also questionable. Material from the more distant (to sites in this study) locality Andarak, is largely reposited at the Zoological Institute, St.
Petersburg. Finally, the formation of Kyrgyzstan as an independent nation in the 1990s resulted in increased Western collaboration and an attempt to synthesize some of the regional paleontological work (Averianov and Godinot, 1998, 2005; Erfurt et al., 1999).

Further listings of Neogene fossil faunas from Kyrgyzstan come from an exploratory geologic mapping study for a 1970 Soviet dissertation published in Russian out of Bishkek, Kyrgyzstan (Tarasov, 1970). While this work's intention was the mapping of high angle thrust faults forming the Tien Shan, during its undertaking, vertebrate fossils were discovered in the Kochkor basin of north central Kyrgyzstan (Figure 1). However, the most recent and comprehensive, albeit unpublished, identification of excavated taxa from a Neogene mass death assemblage in Kochkor, comes from McLaughlin (2018), including descriptions of an "ictithere", Hipparion-grade equids, Gazella sp., Cervinae, Samotherium sp., Palaeomerycidae, Chilotherium sp., and additional as yet unidentified Bovidae and Artiodactyla fossils.

Kyrgyzstan is a country with a notable degree of extant biodiversity and species richness, with over 200 endemic plant species, and over 3000 endemic invertebrate and vertebrate species (Ministry of Environmental Protection, 1998). This does not account for the sub-endemic fauna from the larger Tien Shan region at a larger geographic scale (Ministry of Environmental Protection, 1998). This represents a high degree of extant endemism in both the flora and faunal species for a (relatively) small country, which may be due to the geological history of the region, generating a source of vicariance (Ministry of Environmental Protection, 1998). This endemism is worth investigating within the fossil record, as Central Asia represents a key geographic route for faunal exchange across Eurasia and the same tectonic processes operating today were likely in effect throughout the Miocene (Sobel 
A

B

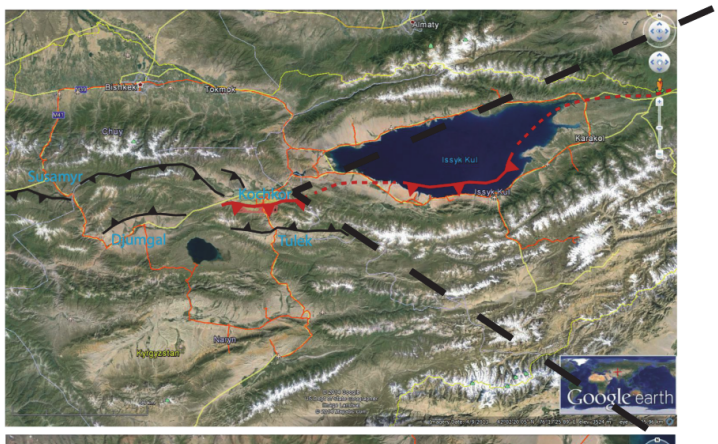

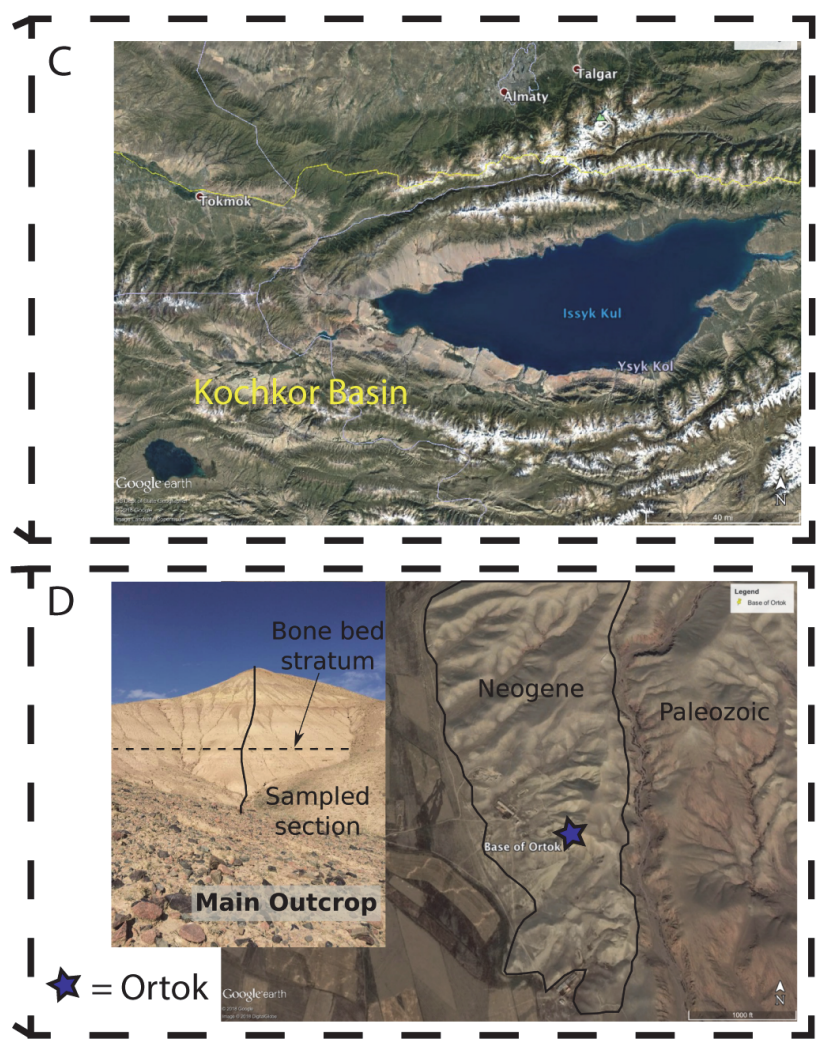

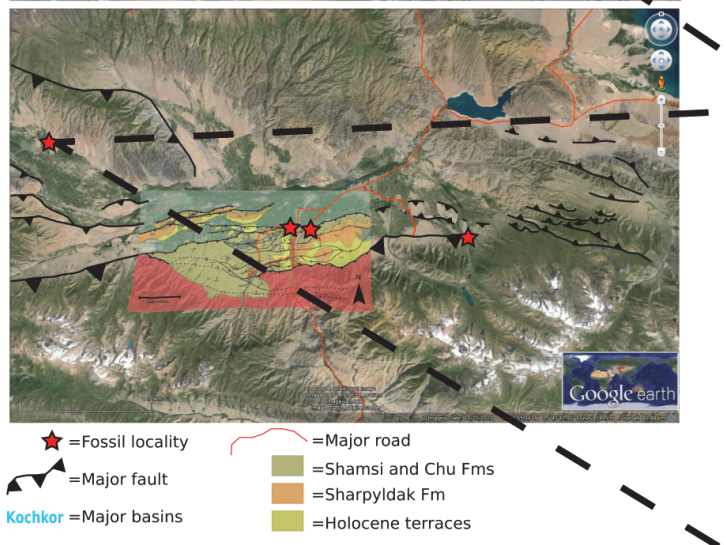

FIGURE 1. Maps of Kyrgyzstan showing the location of Ortok and important topographical structures. A, Google Earth imagery (accessed May 2018) of the Kochkor and Issyk Kul Basins showing major basins, main bodies of water, Tien Shan mountains, and major fault lines for Kyrgyzstan. The Tien Shan mountains run roughly east to west, leaving high altitude basins infilled with Cenozoic sediments between each sub range. The Kochkor Basin is roughly $80 \mathrm{~km}$ long and $24 \mathrm{~km}$ wide. Map data: Google, Mapabc.com. Scale equals $96 \mathrm{~km}$; B, additional zoomed in map of Kochkor Basin with fossil localities. Furthest left star is the Ortok site, other fossil collections are from both Tarasov (1970) and McLaughlin (2018). Map data: Google, Digital Globe. Scale equals 16.2 km; C, zoomed in Google Earth map of Kochkor Basin showing main body of water and topographic features. Likely, the Kochkor Basin was connected to the Issyk Kul Basin (the large lake in the figure) until geologically very recently, as shown by the low hills dividing the two basins. Map data: Google, Landsat Copernicus. Scale equals $65 \mathrm{~km}$; D, Google Earth imagery of the Ortok. Base of measured stratigraphic and paleomagnetostratigraphic section (see McLaughlin, 2018) marked with a blue star. Fossiliferous outcrop extends to east and north of the star in the pale tan exposure. To the east, a gorge cut into reddish Paleozoic granite with the thin layer of Chu unconformably resting on it. Strata at Ortok are dipping very gently to the north and are the least deformed structurally of any site included in this study. Additionally, the fossils are the least diagenically altered, indicating little to no diagenic alteration to the site as well. Map data: Google, Digital Globe.Map Scale equals $300 \mathrm{~m}$.

and Dumitru, 1997; Abdrakhmatov et al., 2001; McLaughlin, 2018). Focusing on the youngest of the Kyrgyz sites from the Chu Formation in the Kochkor basin - the site of Ortok - this paper provides a thorough published description of two Kyrgyz carnivores - Adcrocuta eximia and c.f. Paramachaerodus - with hypotheses for the biodiversity and paleoecology of the Chu Formation and faunal exchange across Kyrgyzstan.

\section{GEOLOGIC SETTING}

Today, Kyrgyzstan has the highest seismic hazard index of any country in the world (Abdrakhmatov et al., 2001). This immense amount of tectonic activity derives from the collision of the Indian sub-continent into Asia generating the Himalayas, among other geologic provinces. Among the latter, the Tien Shan mountain range of Central Asia has some of the highest uplift and convergence rates in the world, accommodating the excess stress not afforded by the Himalaya's uplift (Sobel and Dumitru, 1997; Abdrakhmatov et 
al., 2001). These rapid rates of uplift exhume Paleozoic and Mesozoic basement rocks that form the source material for Neogene sedimentary sequences, generating not only the high elevation mountains of the Tien Shan itself, but sedimentary basins that record a nearly continuous record of deposition from the Eocene to the Present (McLaughlin, 2018).

However, the approximate tempo and mode of uplift for this region is still contentious and poorly understood. Macaulay et al. (2016) determined via stable isotope analysis that the Terskey Range (eastern Kyrgyzstan) of the Tien Shan saw uplift around 25-20 Ma, with additional fluctuations (possibly due to regional rain shadow effects) around 22.6 or $16.9 \mathrm{Ma}$. However, similar rain shadow effects detected via pedogenic isotopic analysis proposed uplift for the northern Tien Shan (eastern Kazakhstan) during the latest Miocene ( $<10 \mathrm{Ma}$; Caves et al., 2017). Additionally, an intermediate value derived from paleomagnetic analyses along the Jingou River of Xinjiang Province, China, recovered two significant increases in sediment accumulation rates at approximately 16-15 Ma and again at approximately 11-10 $\mathrm{Ma}$ (Charreau et al., 2009). Finally, a single late ( 12 Ma), and since sustained, rate of tectonism has been proposed for the central Tien Shan (Makarov, 1990; Sadybakasov, 1990; Abdrakhmatov et al., 2001). These differential dates could reflect distinct regional patterns or a time-lagged common cause. Regardless, additional work from novel datasets is needed.

\section{Kochkor Basin Stratigraphy}

The Kokturpak Formation is composed of Eocene red beds unconformably overlain by the Neogene sytectonic sediments reflecting the initiation and continued uplift of the Tien Shan. Overlying the Kokturpak sediments are the typically coarse-grained, immature conglomerates and sandstones of the Shamsi Formation. The Shamsi grades upward into the uniformly finer-grained Chu Formation, which is in turn conformably overlain (and in some localities interbedded with) the Sharplydak conglomerate, inferred to represent the onset of Pleistocene glaciation (Figure 2). The Chu Formation is a relatively mature sequence of clastic and evaporitic sedimentary rocks, with sandstone and conglomerate lenses interpreted as braided river channels of moderate size and fanglomerate alluvial material (Abdrakhmatov et al., 2001). Finer-grained sediments and evaporites, interpreted largely as overbank deposits, form the majority of the sequence, with the coarse-grained material in discrete lenses. This suggests the Chu Formation was deposited by large, integrated drainage systems (Abdrakhmatov et al., 2001) reflecting the rapid uplift of the mountains at the basin margins. Lithostratigraphically, the formation primarily contains finer-grained material of tan to reddish and greenish silts (Mikolaichuk et al., 2008), whereas by the northernmost edge of deposition represented at Ortok, the sediments are tancolored and lack any of the larger clastic components closer to the erosional source.

\section{Fossil Locality — UO-4605 Ortok}

All specimens described here were recovered in reasonably intact condition from the Ortok locality at the North-western end of the Kochkor Basin, located in the Chu Formation of Kyrgyzstan (Figure 1). Ortok is the only Neogene sediment exposed on the northwest margin of the Kochkor Basin, yet it is still limited in total exposure (Figure 2). It unconformably overlies much older basement rock, with the Quaternary colluvium onlapping the exposed sediments. This site was discovered by Tarasov (1970) while conducting geologic mapping of the basin for doctoral research, and later included in the biostratigraphic work of Sotnikova et al. (1997), but in both cases the actual geographic location is vague (only about a few meters of stratigraphy over an area of a few hundred square meters). While the geographic extent and stratigraphic thickness of the locality is limited, Ortok represents the only outcropping Neogene stratigraphy on the Northern margin of Kochkor Basin. Thus, we are confident the locality is the same as that referred to by Sotnikova et al. (1997) and Tarasov (1970). Stratigraphic correlation and extensive geologic mapping in the basin suggest Ortok is the youngest of the Kyrgyz bone beds from the Chu Formation. Definitive placement is complicated by both the lack of radiometrically dateable sediments, extensive alluvial cover, and complex geologic structure separating Ortok from all other outcrops of Neogene material. Using bioand magnetostratigraphy, the Chu Formation is attributed to the late Miocene through Pliocene, deposited approximately 8 to $4 \mathrm{Ma}$ (Abdrakhmatov et al., 2001; Paulson, 2013).

Ortok is limited in extent of exposure in terms of stratigraphic thickness, but is also the most consistently fine-grained of Chu exposures in Kochkor Basin, as the source material for the Chu Formation in the Kochkor Basin uniformly originates from the southern margin, prograding out into the basin (Paulson, 2013), before finally onlapping Jurassic 

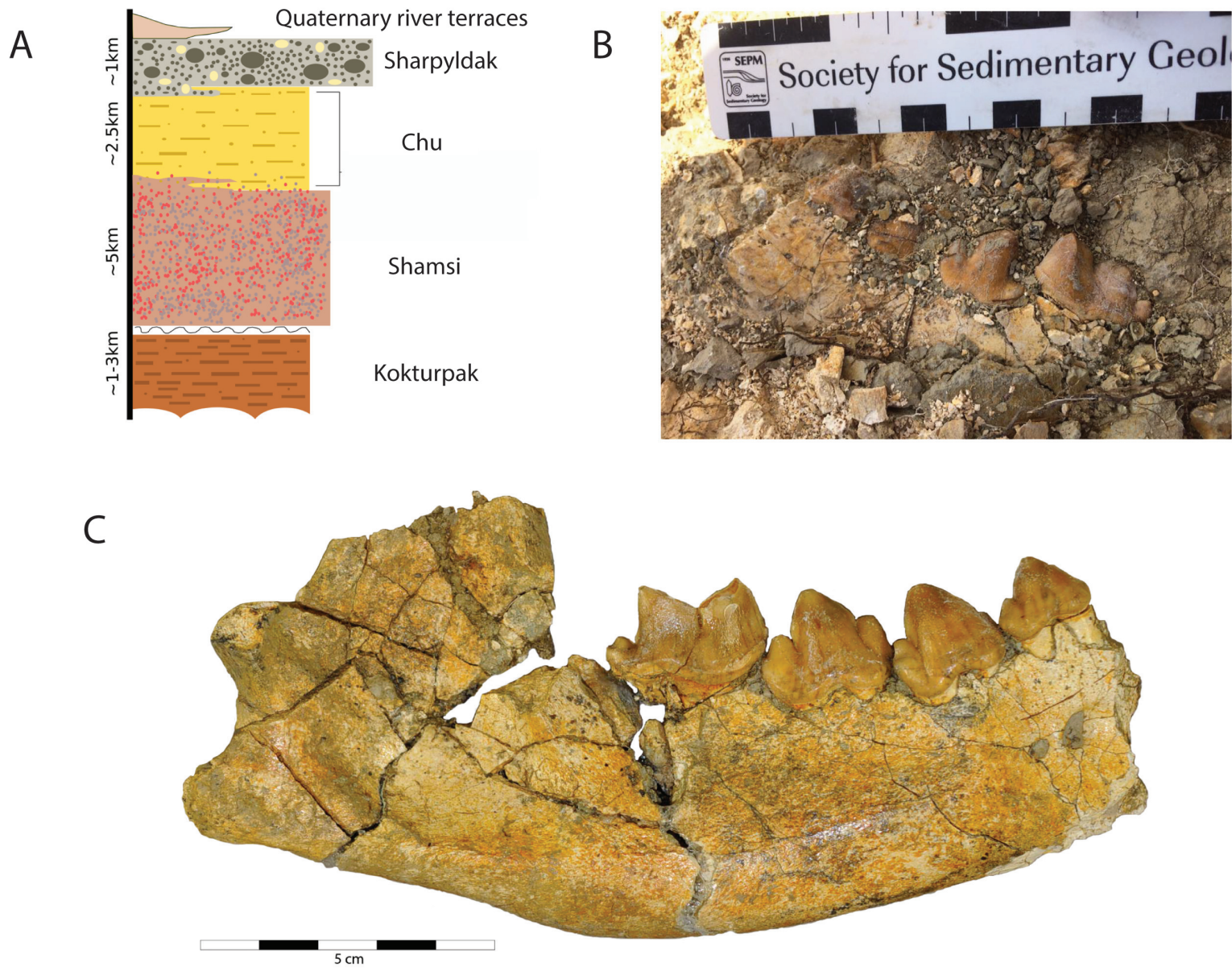

FIGURE 2. Stratigraphy, sediment and partially reconstructed fossil from Ortok site. A, Schematic and generalized stratigraphic column for the Cenozoic formations outcropping in the Kochkor Basin. Relative average grainsize is indicated by the $X$ axis, while stratigraphic position is related on the $Y$ axis; $B$, specimen UOMNH F-70508 in situ prior to removal by W.N.F. McLaughlin to demonstrate fossil completeness and surrounding matrix. Scale bar equals $10 \mathrm{~cm}$; C, cleaned and reconstructed UOMNH F-70508. Note: some diagnostic features were damaged and lost during preparation; see Figure 3 for complete specimen. Scale bar equals $5 \mathrm{~cm}$.

granites and older Paleozoic rocks (Mikolaichuk et al., 2008) in the northwest margin to form Ortok. The entire sequence is siltstone to claystone and is uniformly tan to cream in color (Figure 2). Ortok has a possible age of 4.9 to $7.7 \mathrm{Ma}$ (McLaughlin, 2018), although in future studies, this could be constrained by both biogeographic findings and magnetostratigraphy (Abdrakhmatov et al., 2001; McLaughlin, 2018). Temporal constraint is further provided for this site by the ranges (and extinction) of common Neogene taxa such as Hipparion-grade horses, Chilotherium, Samotherium, and cervinegrade deer (McLaughlin, 2018). The abundance of certain Chilotherium taxa (see McLaughlin, 2018 for full discussion), suggest that the site of Ortok is possibly situated within the late Miocene part of the Chu Formation, but as suggested above, this cannot be confidently assigned. Both the carnivorans and the considerably more abundant ungulates are most consistent with Asian Hipparion Fauna, while sharing fewer faunal similarities with contemporary, and geographically closer, Siwalik or Samos Faunas.

\section{MATERIALS AND METHODS}

\section{Methods}

Measurements. Guidelines and measurements were following from Werdelin and Solounias (1991) and von den Driesch (1976). We used Carrera precision calipers for measurements, with a given accuracy of $0.0254 \mathrm{~mm}$. The measurements in Table 1 and their respective definitions are labelled according to Werdelin and Solounias (1991) and von den Driesch (1976). 
TABLE 1. Measurements (in mm) of UOMNH F-70508 with comparative materials from published studies and museum collections, using criteria from Werdelin and Solounias (1991). Abbreviations: Lp2, Lp3, Lp4, Lm1: anteroposterior length of respective tooth; Lpp4: length of major cusp of p4; Ltm1: Length of trigonid of m1; Wp2, Wp3, Wp4, Wm1; transverse width of respective tooth; Cond-ang: distance from dorsal margin of condyle to ventral margin of angular process; p2-m1: inclusive distance between p2 and m1; Hdia: dorsoventral depth of mandible at diastema; Hbehm1: dorsoventral depth of mandible behind m1; LP4: anteroposterior length of LP4; WaP4: width of p4 at protocone; WbIP4: width of p4 between paracone and metastyle; Lpp4/LpP4: length of paracone of p4/P4; LmP4: length of metastyle of p4; WS90: Werdelin and Solounias (1990); WK99: Werdelin and Kurtén (1999); G11: Ghaffar et al. (2011).

\begin{tabular}{|c|c|c|c|c|c|c|}
\hline \multirow[b]{2}{*}{ Measurement } & \multirow{2}{*}{$\begin{array}{l}\text { UOMNH } \\
\text { F-70508 }\end{array}$} & \multicolumn{2}{|c|}{ Comparative specimens } & \multicolumn{3}{|c|}{ Published ranges of $A$. eximia } \\
\hline & & Range & ID & Range & Mean \pm SE & Reference \\
\hline Lp2 & 16.39 & - & - & $14.8-17.8$ & $16.01 \pm 0.11$ & WK99, G11 \\
\hline Wp2 & 10.97 & - & - & $9.5-13.3$ & $11.56 \pm 0.10$ & WS90, WK99, G11 \\
\hline Lp3 & 22.44 & $19.63-19.68$ & AMNH 22880; F:AM 144903 & $15.7-22.1$ & $19.73 \pm 0.21$ & WK99, G11 \\
\hline Wp3 & 13.69 & $12.84-14.30$ & AMNH 22880; F:AM 144903 & $10.3-15.3$ & $13.38 \pm 0.13$ & WS90, WK99, G11 \\
\hline Lp4 & 22.78 & $21.73-22.06$ & AMNH 22880; F:AM 144903 & $20.2-24.7$ & $22.27 \pm 0.17$ & WK99, G11 \\
\hline Wp4 & 13.9 & $13.29-13.31$ & AMNH 22880; F:AM 144903 & $12.0-14.6$ & $13.02 \pm 0.09$ & WS90, WK99, G11 \\
\hline Lpp4 & 11.31 & - & - & $9.5-12.1$ & $10.79 \pm 0.07$ & WS90, WK99, G11 \\
\hline Lm1 & 29.2 & $25.88-26.92$ & AMNH 22880; F:AM 144903 & $24.4-29.5$ & $27.16 \pm 0.19$ & WK99, G11 \\
\hline Wm1 & 12.46 & - & - & $11.2-14.4$ & $12.75 \pm 0.09$ & WK99, G11 \\
\hline Ltm1 & 23.68 & $21.24-22.90$ & AMNH 22880; F:AM 144903 & $20.3-26.8$ & $22.35 \pm 0.20$ & WK99 \\
\hline Cond-ang & 41.7 & - & - & $28.0-39.0$ & 33.5 & WS90 \\
\hline $\mathrm{p} 2-\mathrm{m} 1$ & 82.59 & - & - & $77.8-88.1$ & 81.88 & WS90 \\
\hline Hdia & 36.96 & - & - & $30.0-50.0$ & 43.39 & WS90 \\
\hline Hbeh m1 & 48.57 & $46.62-51.71$ & AMNH 22880; F:AM 144903 & $29.7-54.2$ & 46.46 & WS90 \\
\hline LP4 & 34.89 & $34.86-38.79$ & $\begin{array}{l}\text { AMNH 22880, 23016, 27800, } \\
26372\end{array}$ & $32.9-40.8$ & $37.82 \pm 0.27$ & WS90, WK99, G11 \\
\hline LpP4 & 11.57 & $12.13-13.66$ & $\begin{array}{l}\text { AMNH 22880, 23016, 27800, } \\
\text { 26372; China -41L-339 }\end{array}$ & $10.2-14.5$ & $12.80 \pm 0.12$ & WS90, WK99, G11 \\
\hline LmP4 & 13.84 & $13.87-15.61$ & $\begin{array}{l}\text { AMNH 22880, 23016, 27800, } \\
\text { 26372; China -41L-339 }\end{array}$ & $14.0-16.9$ & $15.60 \pm 0.12$ & WS90, WK99, G11 \\
\hline WaP4 & 16.81 & $16.44-20.24$ & $\begin{array}{l}\text { AMNH 22880, 23016, 27800, } \\
26372\end{array}$ & $15.2-20.3$ & $18.40 \pm 0.20$ & WS90, WK99, G11 \\
\hline WbIP4 & 11.17 & $10.94-13.25$ & $\begin{array}{l}\text { AMNH 22880, 23016, 27800, } \\
26372\end{array}$ & $10.1-14.0$ & $12.12 \pm 0.11$ & WS90, WK99, G11 \\
\hline
\end{tabular}

Institutional abbreviations. UOMNH, University of Oregon Museum of Natural and Cultural History, Eugene, Oregon, USA; FMNH, Field Museum of Natural History, Chicago, Illinois, USA; AMNH, American Museum of Natural History, Division of Paleontology, New York, New York, USA; F:AM, American Museum of Natural History, Frick Collection, New York, New York, USA; UF, Florida Museum of Natural History, University of Florida, Gainesville, Florida, USA; LACMHC, Los Angeles County Museum, George C. Page Museum (Hancock Collection), Los Angeles, California, USA.

Terminology. We use cusp terminology following standard convention for describing Carnivora dentition, with description of morphology sensu Solé and Ladevèze (2017) and Werdelin and Solounias (1991).
Phylogeny and taxonomy. The phylogenetic placement of Adcrocuta in this study follows Werdelin and Solounias (1991) and McKenna and Bell (1997). Briefly, A. eximia was originally described as Hyaena eximia Roth and Wagner, 1854, then attributed to the genus Crocuta Kaup, 1829, and finally allocated to the genus Adcrocuta Kretzoi, 1938. Werdelin and Solounias (1991) have an extensive list of synonymies for $A$. eximia, which is monospecific with $A$. eximia being the only species within the genus Adcrocuta (Turner et al., 2008). It has also been argued that $A$. eximia can be compared to extant spotted hyena Crocuta crocuta (de Bonis, 2005). It should be noted that there is still debate concerning hyaenid systematics (see Werdelin and Solounias, 1991). An analysis of the phylogenetic position of Adcrocuta will not be 
undertaken in this paper as it does not impact the identification of this specimen, but the authors acknowledge that there is still debate regarding the placement of Adcrocuta within Hyaenidae.

Using mitochondrial sequences of Pleistocene machairodontines, the divergence of that group from extant felines is estimated to have occurred 18.2 to 22.0 m.y.a. (95\% credibility interval; Paijmans et al., 2017). Within the Machairodontinae, several lineages are argued to evolve from this common sabercat ancestor, namely the tribes Smilodontini, Homotherini, and Metailurini, with inferred Eurasian origins (Werdelin et al., 2010; Christiansen, 2013). It is within Smilodontini that the genus Paramachaerodus has historically been thought to originate (e.g., Werdelin et al., 2010), but recent cladistic analyses cast doubt on that hypothesis, instead favoring a more stem position, relative to the aforementioned tribes, within the Machairodontinae (Christiansen, 2013; Wallace and Hulbert, 2013; Spassov and Geraads, 2015). In Li and Spassov's (2017) taxonomic review of the Paramachaerodus genus, they recognize four valid species forming a grade of increasingly derived saber-tooth morphs. While a full discussion of the taxonomic revisions of Machairodontinae is not the topic nor within the scope of this paper, it should be noted that the most recent and comprehensive phylogenetic and taxonomic revision of Paramachaerodus by Li and Spassov (2017) will be used in this study.

\section{Materials}

Comparative materials. In addition to the direct observations and measurements of the fossils, we visited and used museum specimens (listed below) for identification and comparison to our specimens, supplemented with data from available published sources. While published data on Central Asian fossil Hyaenids is useful for the primary source of comparative data, published metrics of Adcrocuta eximia were also considered to account for the highly variable nature of this extinct species. The comparative museum specimens of $A$. eximia (maxillary and mandibular dentition), included AMNH 26373, AMNH 22880, AMNH 140301, AMNH 140298, AMNH 140299, AMNH 140300, and F:AM 144903. Measurements and cusp ratios were also used from these specimens, along with published metrics from Werdelin and Solounias (1990), Werdelin and Kurtén (1999), Ghaffar et al. (2011), and Koufos (2016). Comparative specimens of Paramachaerodus were unavailable at the visited museums, so images and measurements from publications were used for identification (Salesa et al., 2010; Siliceo et al., 2014; Li and Spassov, 2017).

Phylogenetic analysis. We tested the phylogenetic placement of UOMNH F-70509 by scoring the specimen into the character matrix of $\mathrm{Li}$ and Spassov (2017), the same matrix used in their taxonomic revision of the Paramachaerodus genus. To this, we added one additional character (19. M1, number of roots. 0 , three; 1 , two; 2 , one.) to describe the reduction of the first upper molar of species within this genus, and a feature visible for our specimen. The resultant character matrix (see Appendix 1) was analysed under the parsimony optimality criterion in TNT 1.5 (Goloboff and Catalano, 2016) via implicit enumeration with unordered characters and the taxon Proailurus lemanensis as the outgroup.

\section{SYSTEMATIC PALEONTOLOGY}

Family HYAENIDAE Gray, 1821

Subfamily HYAENINAE Gray, 1821

Genus ADCROCUTA Kretzoi, 1938

Adcrocuta eximia (Roth and Wagner, 1854)

Figures 3-5

Synonymy. Refer to Werdelin and Solounias (1991) for list and discussion of synonymy

Type species. Hyaena eximia (Roth and Wagner, 1854, 396-398)

Occurrence. Bahean-Daodean; Vallesian-Turolian; MN Zones 10-13; Late Miocene

Localities. Bulgaria, China, France, Greece, Hungary, Iran, Libya, Pakistan, Romania, Spain, Turkey, Russia, and Yugoslavia (Werdelin and Solounias, 1991); UO-4605 Ortok.

Referred specimen. UOMNH F-70508

\section{Description}

Preserved material consists of a lower right partial dentary, isolated left $\mathrm{p} 3$ and P4 (Figures 3 and 4). The angular process and condyloid process are intact, but the coronoid process is damaged and incomplete (Figure 3A). The mandibular corpus is elongated, high, and thick $(13.3 \mathrm{~mm})$, and the inferior border is convex. At the horizontal ramus below the $\mathrm{m} 1$, it curves deeper and rises at the ventral border at a $12^{\circ}$ angle. There are two mental foramina (Figure 3 ); the anterior foramen mentale is located $11 \mathrm{~mm}$ below the distal root of the $\mathrm{p} 2$, the smaller posterior foramen mentale is $16.5 \mathrm{~mm}$ below the mesial root of $\mathrm{p} 3$. The foramina are both positioned in the upper half of the ramus. The mandibular depth is $46.8 \mathrm{~mm}$ behind the $\mathrm{m} 1$ (lingual) and $36.4 \mathrm{~mm}$ between the p2 and p3 (lin- 

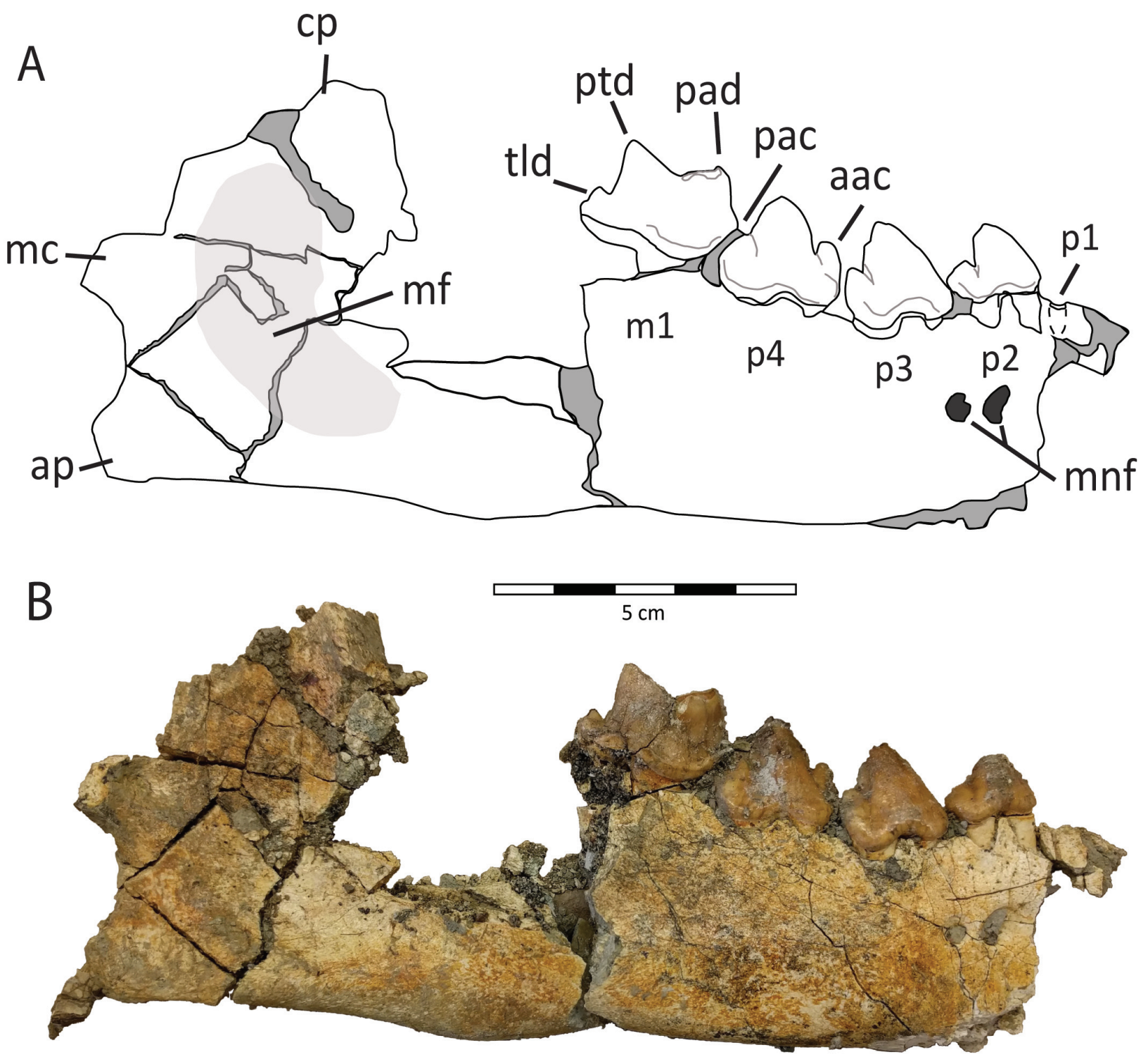

FIGURE 3. Specimen UOMNH F-70508, Adcrocuta eximia, right partial mandible, pre-breakage and reconstruction. A, annotated line drawing of buccal view, demonstrating two mental foramina and partial preservation of masseteric fossa (light grey). Note alveolus of p1 anterior to p2; B, UOMNH F-70508 after excavation and preliminary reconstruction demonstrating diagnostic features. Abbreviations: aac, anterior accessory cusp; ap, angular process; cp, coronoid process; mc, mandibular condyle; mf, masseteric fossa; mnf, mental foramina; pac, posterior accessory cusp; pad, paraconid; ptd, protoconid; tld, talonid. Scale bar equals $5 \mathrm{~cm}$.

gual). Behind the $\mathrm{m} 1$, the mandible is generally deeper, but due to the broken mandibular surface, we could not take reliable measurements. A portion of the fossa masseterica is preserved (Figure 3B); it is oval, relatively deep, and the anterior portion ends $28 \mathrm{~mm}$ from the distal end of the $\mathrm{m} 1$. This measurement could be impacted by preservation (Figure 3). The angular process is quite well-preserved and is in line with the alveolar end of the $\mathrm{m} 1$.
Upper dentition. The upper carnassial P4 is elongated and slender with a strongly reduced protocone (Figure 4). The protocone is a distinct conical cusp that projects anterolingually between the parastyle and paracone (Figure 4A). As characterizes Adcrocuta, the reduced protocone is situated posterior to the anterior margin of the parastyle (Werdelin and Solounias, 1991; Ghaffar et al., 2011; Koufos, 2016). The protocone is low, the parastyle is lower than the paracone, and the 
A

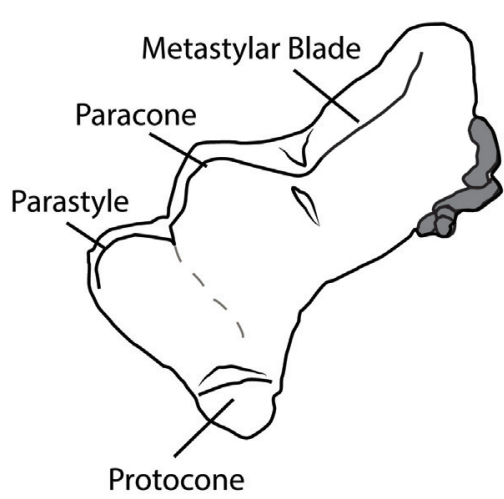

B

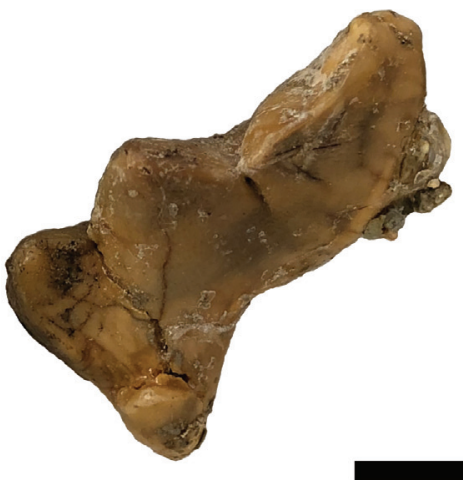

C

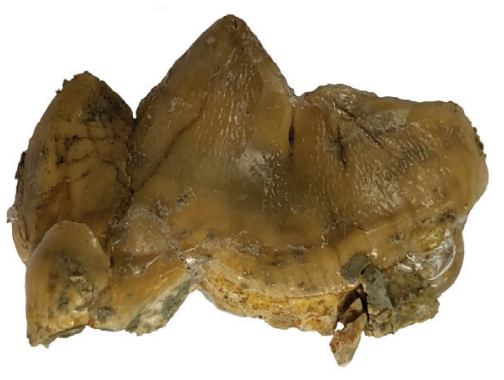

FIGURE 4. Isolated left P4 of UOMNH F-70508, Adcrocuta eximia. A, schematic of preserved features in occlusal view; B, occlusal view of specimen displaying minimal wear on metastylar blade; $\mathbf{C}$, lingual view of specimen. Note reduced protocone that does not extend anterior to the anterior face of the parastyle. Scale bar equals $10 \mathrm{~mm}$.

metastyle blade is long with a buccally angled distal end (Figure 4A).

Lower dentition. The dentition is well-preserved and a small rounded alveolus for the $\mathrm{p} 1$ is present (Figure 5A). The other premolars, p2 to p4, increase in size posteriorly (Figure $5 \mathrm{C}$ ). The $\mathrm{p} 2$ has two roots, with a large ovoid protoconid that is unworn. The mesial cingulum thickens, but there is no anterior accessory cuspid. There is a posterior accessory cuspid that is closely appressed to the main cuspid (protoconid). The p3 has the same features as the $p 2$, although the thickening of the cingulum is slightly greater, and it is larger and more robust in general. The posterior accessory cuspid is slightly larger than in the p3 but is still closely appressed to the main cuspid. There is a shallow lingually situated basin between the posterior accessory cuspid and the main cuspid. The position of the p3 is slightly lower than the p2 in the mandible. The p3 is near equal in size to the p4 in width and length. The p4 is the largest and most robust premolar, with a large anterior accessory cuspid separated from the main cuspid, and a smaller posterior accessory cuspid. The posterior accessory cuspid is situated on the buccal side of the distal projection of cingulum. There is a narrow open basin between the smaller posterior cuspid and the main cuspid apparent on the lingual side, similar to an $\mathrm{m} 1$ talonid. The lower carnassial $\mathrm{m} 1$ is elongated and relatively narrow. There is no distinct metaconid, and there is a small and low bicuspid talonid (Figure 5E). The talonid is separated from the trigonid by a small groove and there is a very low, distinct hypoconid, and second reduced labial cuspid, separated by a clear but shallow groove (Figure $5 \mathrm{E}$ ). The other small cuspid has been identified as the entoconid. This reduced cuspid was also slightly worn with dentine exposure (Figure 5B). The reduction of the talonid is associated with hypercarnivory, but the continued presence of even a reduced talonid suggests its continued functional use in crushing (Solé and Ladevèze, 2017). There is a shallow talonid basin on the buccal side of the distal projection of the carnassial. The buccal cingulum thickens around the entire carnassial creating a small projection on the trigonid. There is a degree of wear on both the protoconid and paraconid, exposing the dentine with $<1 \mathrm{~mm}$ of enamel around the anterolingual edge, which is minimal wear compared to many specimens of Adcrocuta (based on museum comparatives). There is no trace of an $\mathrm{m} 2$ or any alveoli, however, $A$. eximia has a wide variation in presence of $\mathrm{m} 2$, as well as the presence of $\mathrm{p} 1$, and the presence of a metaconid, so this does not confound our identification (Werdelin and Solounias, 1990; Kovachev, 2012).

\section{Comparisons}

The large size (length and width) of the teeth of UOMNH F-70508, the present alveolus of the first premolar ( $p 1)$, the short $\mathrm{m} 1$ talonid, and the absent $\mathrm{m} 2$ are diagnostic of the Hyaenidae. There are three current subfamilies recognized in Hyaenidae: Ictitheriinae, Hyaeninae, and Percrocutinae (McKenna and Bell, 1997). The morphology of the 


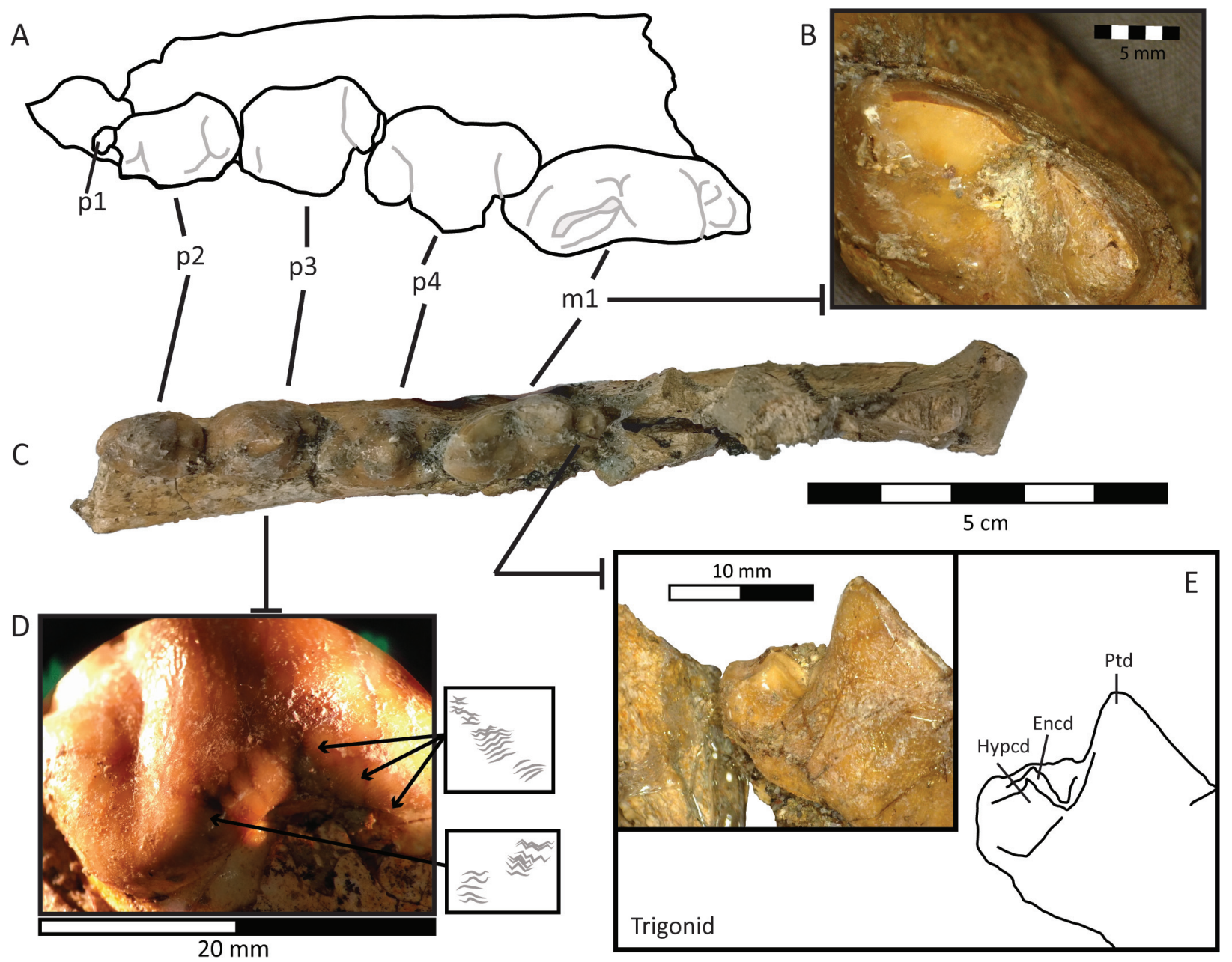

FIGURE 5. Specimen UOMNH F-70508, Adcrocuta eximia, in occlusal view with insets of morphological features discussed in text. A, occlusal schematic diagram of preserved dentition and p1 alveolus (arrow); B, occlusal view of m1 (anterior to the left) illustrating early stage wear on paraconid and protoconid, respectively; C, occlusal of preserved specimen; D, buccal view of p3 showing examples of transitional acute-angle Hunter-Schreger Bands. These are associated with robust hyaenines (Tseng, 2011); E, detail oblique lingual view of talonid of carnassial (m1) with reduced hypoconid and entoconid. Abbreviations: Encd, entoconid; Hypcd, hypoconid; Ptd, protoconid. Scale bar A and $\mathbf{C}$, equals $5 \mathrm{~cm}, \mathbf{B}$, equals $5 \mathrm{~mm}$, $\mathbf{D}$, equals $20 \mathrm{~mm}$, and $\mathbf{E}$, equals $10 \mathrm{~mm}$.

specimen excludes subfamily Ictitheriinae as UOMNH F-70508 does not have a second molar, the premolars are relatively short compared to the carnassial, there is no metaconid, and there is a relatively short talonid (F:AM 144905, 144906; Semenov, 2008).

During the Miocene, there are several possible hyaenids present in Eurasia, including the Percrocutinae hyaenids (Werdelin and Solounias, 1990). The features of UOMNH F-70508 distinguish it from a Percrocuta grandis as our $\mathrm{p} 4$ and $\mathrm{m} 1$ are larger and longer (relative) to the $\mathrm{p} 2$ and $\mathrm{p} 3$ (Howell and Petter, 1985; Ghaffar et al., 2011). Dinocrocuta gigantea was eliminated based on premolar morphology as they possess anterior cusps on $p 2$ and $p 3$, with no $p 1$, unlike the premolars in our specimen UOMNH F-70508 (Zhang, 2005). Generally, the size for Percrocuta mandibular teeth are also substantially larger $( \pm 10 \mathrm{~mm}$ on average, length, and width) than UOMNH F-70508 (Howell and Petter, 1985). Given the disqualification of UOMNH F-70508 from Percrocutinae, the remaining characteristics of the dentition were able to denote membership within the subfamily Hyaeninae, and subsequently the species Adcrocuta eximia. Adcrocuta does share certain derived characteristics with the percrocutoid hyaenids (see Howell and Petter, 1980, 1985; Werdelin and Solounias, 1990). While there is variation in the characteristics of $A$. eximia, diagnostic features 
such as two mental foramina, present lower first permanent premolar, the lower carnassial being longer relative to the fourth premolar, and a less reduced talonid, distinguish Adcrocuta from potential percrocutoid hyaenids (Howell and Petter, 1980, 1985; Werdelin and Solounias, 1990; Kovachev, 2012). The specimen UOMNH F-70508 possesses many of these features, including two mental foramina, present p1, short p2 and p3 relative to the taller $\mathrm{p} 4$ and $\mathrm{m} 1$, absent anterior accessory cuspids in the p2 and p3, absent metaconid and small talonid in the $\mathrm{m} 1$, and lower carnassial longer relative to p4. Therefore, UOMNH F-70508 bears the most similarity to $A$. eximia.

\section{Remarks}

UOMNH F-70508 possesses largely unworn dentition, particularly compared to other adult specimens in museum collections, however, it is not newly erupted either (Figure 5B). The maximum length and width of the $\mathrm{m} 1$ is $2-4 \mathrm{~mm}$ longer and wider than the compared museum specimens (e.g., AMNH 22880, F:AM 144903). This could suggest endemic variation in our specimen compared to other Eurasian Adcrocuta. Ratio of maximum length $\mathrm{m} 1: \mathrm{P} 4$ is within $1.0 \mathrm{~mm}$ of the museum specimens, as is length of paracone:metastyle blade. As mentioned above, $A$. eximia has been considered highly variable within the species, but Werdelin and Solounias $(1990,1991)$ found that there was no statistical significance to this variation, and $A$. eximia are no more variable than any other hyaenids from the same region.

Family FELIDAE Fischer von Waldheim, 1817

Subfamily MACHAIRODONTINAE Gill, 1872

Genus c.f. PARAMACHAERODUS Pilgrim, 1913

Figures 6 and 7

*. 1913 Paramachaerodus Pilgrim, p. 291

1924 Paramachairodus Zdansky, p. 130

*. 1929 Pontosmilus Kretzoi, p. 1298

*.1929 Protamphimachairodus Kretzoi, p. 1316

Type species. Felis ogygia Kaup, 1832, by original designation.

Occurrence. Bahean-Baodean; Vallesian-Turolian; MN Zones 9-13; middle late Miocene, Eurasia. Localities. Bulgaria, China, Germany, Greece, Iran, Spain (Salesa, 2002; Salesa et al., 2010; Li and Spassov, 2017); UO-4605 Ortok, Kyrgyzstan.

Referred specimen. UOMNH F-70509.

\section{Description}

UOMNH F-70509 is associated portions of an adult left M1, $5.42 \mathrm{~mm}$ long (ant.-post.), and 8.11 $\mathrm{mm}$ wide (med.-lat.) at maximal preserved portions; the ventral tip of $\mathrm{C} 1$ with a crown height of $15.69 \mathrm{~mm}$ and cross-sectional dimensions of 4.35 $\mathrm{mm}$ wide by $8.17 \mathrm{~mm}$ long at maximal preserved portions; and the paracone of left P4, $11.43 \mathrm{~mm}$ tall, $5.63 \mathrm{~mm}$ wide, and $8.99 \mathrm{~mm}$ long at maximal preserved portions (Figure 6). The majority of the M1 (Figure 6E-F) is preserved including a buccally directed parastyle, paracrista, centrocrista, and metacone, while the lingual portion of the tooth is not preserved. The tooth is greatly reduced relative to the remaining preserved dentition, while additionally lacking a prominent paracone or metacone. However, it can be inferred that the tooth would have been triple-rooted, with two preserved roots and one more supporting the area associated with the non-preserved protocone. The C1 (Figure 6AC) is greatly medially-laterally compressed, preserved ratio of length to width 1.88 , with an anterior keel and incipient coarse crenulations on the posterior edge, producing a serration density of 2.6 serrations per millimeter (5 denticles/1.90 mm). The paracone of P4 (Figure 6G-I) displays a near vertical buccal margin while a dorsal-lingually flared lingual margin as it extends towards the nonpreserved protocone. The anterior and posterior edge display thin cristae, while the posterior edge is additionally modified into the anterior portion of the carnassial notch with vertical orientation. No apparent wear is visible on this cusp indicating that the tooth may have been newly erupted at the time of the individual's death.

\section{Comparisons}

The hypercarnivorous morphology of the preserved dentition of UOMNH F-70509, with greatly reduced $\mathrm{M} 1$ and medially-laterally compressed canine with coarse denticles on its posterior edge, are diagnostic of the Felidae, specifically the Machairodontinae (Gill, 1872). Saber-tooth morphology is not solely diagnostic of the machairodontine felids; for this time period, Miocene nimravids such as Barbourofelis are possible, but UOMNH F70509 differs in its lack of labial and lingual grooves on the $\mathrm{C} 1$, relatively large $\mathrm{M} 1$, and inferred presence of protocone (Bryant, 1991). Additionally, comparisons of serration density, which has been shown to have generic diagnostic utility (Barrett, 2016), to machariodontine felids and Late Miocene nimravids reveals that UOMNH F-70509 falls within the range of saber-toothed felids (1.1-2.6 serrations per millimeter), while substantially outside that of Late Miocene nimravids (3.7-4.3 serrations per millimeter) (see Appendix 2). 
A
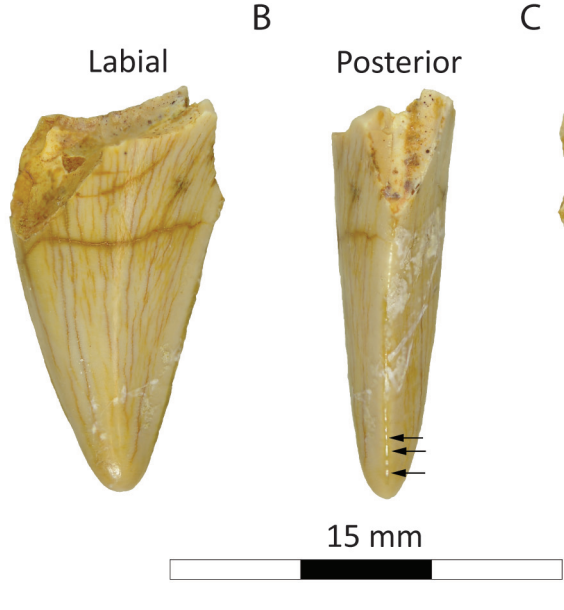

$\mathrm{E}$

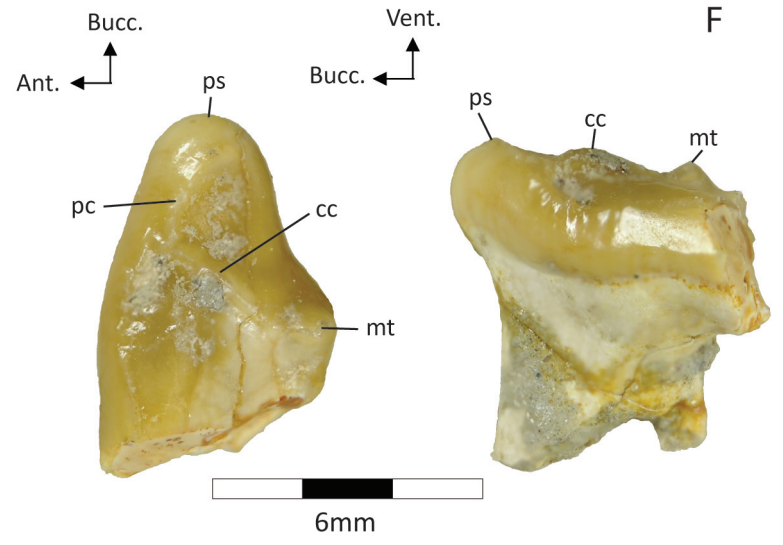

C

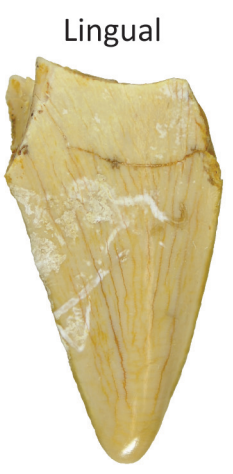

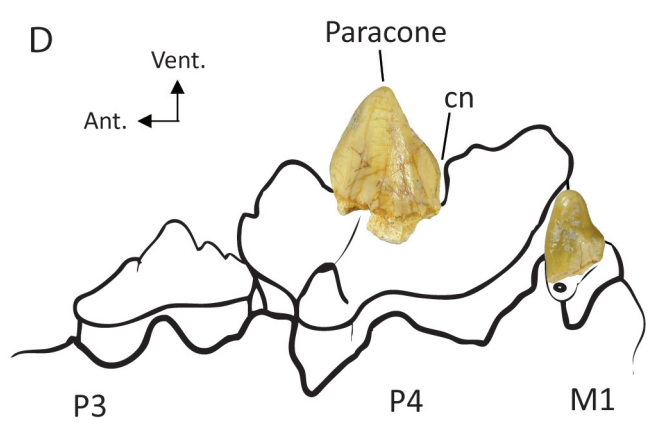

G
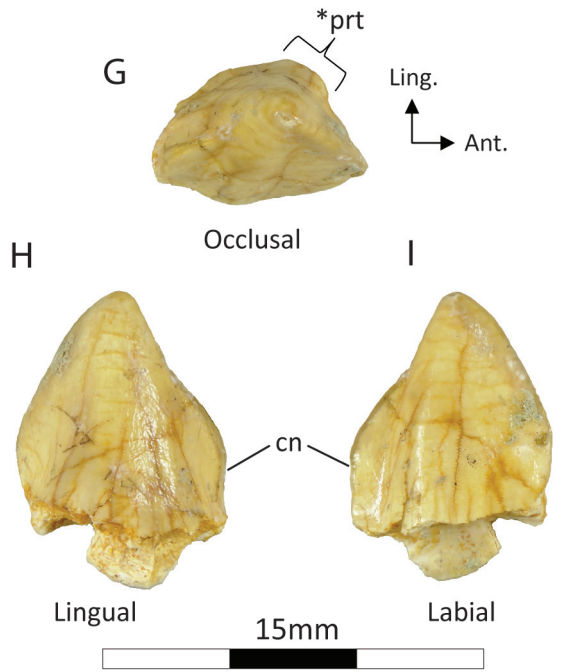

FIGURE 6. Annotated views of UOMNH F-70509, cf. Paramachaerodus. A, distal tip of canine, labial view; B, distal tip of canine, posterior view, note incipient crenulations on posterior edge (arrows); C, distal tip of canine, lingual view; D, schematic representation of preserved post-canine elements, not to common scale, inferred missing anatomy modified from Li and Spassov (2017); E, occlusal view of preserved left M1; F, anterior view of preserved left M1; G, occlusal view of preserved P4 paracone; $\mathbf{H}$, lingual view of preserved P4 paracone; I, labial view of preserved P4 paracone; Abbreviations: cc, centrocrista; cn, carnassial notch; mt, metacone; pc, paracrista; *prt, flared portion of paracone cusp leading to protocone; ps, parastyle. Scale bar A-C, and G-I, equals $15 \mathrm{~mm}$, E-F, equals $6 \mathrm{~mm}$.

Several species of late Miocene machairodontines are present in Asia. The features of UOMNH F-70509 preclude inclusion into the morederived "dirk-tooth" machairodontines, typically with clearly defined canine denticles (though Megantereon cultridens lacks denticles), minute $\mathrm{M} 1$, and near absent P4 protocone. Instead UOMNH F-70509 better fits with the features of "scimitar-toothed" machairodontines, specifically Paramachaerodus (Pilgrim, 1913). A recent review of this genus combines it with the genus Promegantereon (now a junior synonym of Paramachaerodus) into a grade of like-forms (Li and Spassov, 2017). This grade has Paramachaerodus ogygia (Kaup, 1832) as its basal-most member, lacking crenulations on its canines, a sinusoidal buccal border of the P4, and an elongated M1 with "...two roots; [having] a buccolingually lengthened crown, with a slight ridge extending from the mesiobuccal to the lingual borders" (Siliceo et al., 2014, p. 412). The more derived $P$. maximiliani (Zdansky, 1924) on the other hand, possesses well-defined canine denticles, a straight buccal border to the P4, a reduced protocone on the $\mathrm{P} 4$, and a single rooted M1 (Li and Spassov, 2017). Specimen UOMNH F70509 possesses a combination of these features, as is true of several other recently reported Eurasian specimens (Li and Spassov, 2017), but bears the most similarity to the above diagnostic features of Paramachaerodus ogygia. However, it does differ in the nascent denticles on the posterior edge of the canine and triple-rooted M1, though this latter feature may be a result of individual variation given that the third root is minute in dimensions. 


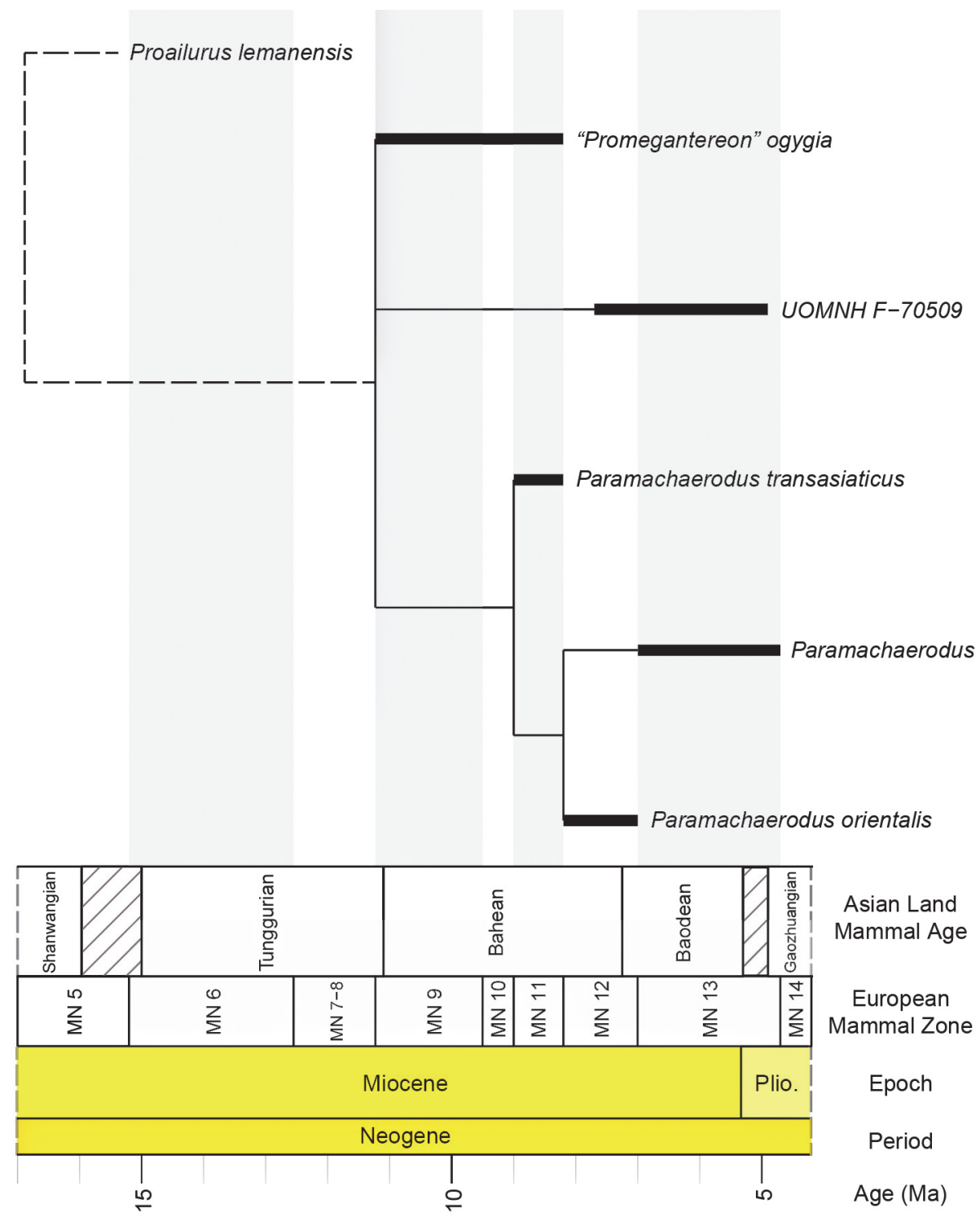

FIGURE 7. Time-scaled phylogeny of the Paramachaerodus genus and UOMNH F-70509's placement within it. The depicted tree is a strict consensus of two most-parsimonious trees of score 32. Note the location of UOMNH F-70509 as unresolved relative to "Promegantereon" ogygia at the base of the genus even though it occurs much later in the rock record. Time-scaling was performed in R, version 3.6.1 (R Core Team, 2019) with the Strap package (Bell and Lloyd, 2014) using the "basic" method. Taxa ages derive from Li and Spassov (2017). The outgroup taxon Proailurus lemanensis has an Oligocene occurrence, not shown for clarity, but its basal position in our analysed taxa is depicted with dotted lines.

\section{Remarks}

The earliest taxon is Paramachaerodus ogygia, which is known only from MN 9-11 of Europe (Salesa et al., 2010). Subsequently, the taxon $P$. transasiaticus diverges with an occurrence in the latter half of MN 11 (Bahean, Asian Land Mammal Age) of China and Bulgaria, followed by P. orientalis in MN 12 of Iran and Europe (Salesa et al., 2010; Qiu et al., 2013; Li and Spassov, 2017).
Finally, the last occurring and most derived taxon, $P$. maximiliani, appears in the late Bahean to Baodean of China (MN 11-13) and with a single occurrence in MN 13 of Spain (Salesa et al., 2010). Preserved diagnostic characters place the Kyrgyz specimen closest to $P$. ogygia, though with certain features similar to that of $P$. transasiaticus, such as incipient crenulations on the canine. However, the age of the Kyrgyz specimen, approximately $6 \mathrm{Ma}$, 
is substantially younger than what is known for either of these above-mentioned taxa. One hypothesis is that the Kyrgyz specimen represents an endemic taxon that has evolved some additional saber-tooth characteristics during its unsampled time interval from a European originating, $P$. ogygia-like ancestor. An additional hypothesis is that it constitutes a new species splitting off from an ancestral Asian Paramachaerodus ancestor, also unsampled in Central Asia. However, we feel a new species designation would require additional fossil material to adequately assess this Kyrgyz saber-tooth cat.

\section{PHYLOGENY}

An implicit enumeration search, which finds the guaranteed most-parsimonious, or set of mostparsimonious trees (those with the lowest transformation cost), returned two trees of a cost of $32(\mathrm{Cl}$ : 0.93, RI: 0.83). The trees were summarized via strict consensus and can be seen in Figure 7. The two most-parsimonious trees only differed in the most basal taxon of the genus, either "Promegantereon" ogygia, or our specimen UOMNH F-70509. Tip-ward of this polytomy was recovered the pectinate arrangement of Paramachaerodus transasiaticus, $P$. orientalis and $P$. maximiliani, the same arrangement as found in Li and Spassov (2017)'s original analysis (see Appendix 1).

\section{DISCUSSION}

\section{Ortok Biodiversity}

The fossil fauna from Late Miocene-Early Pliocene Ortok is composed primarily of large ungulate taxa with Rhinocertotidae, Equidae (e.g., Hipparion), Cervidae, Bovidae, and Giraffidae (McLaughlin, 2018). The presence of Hipparion provides a temporal constraint as they do not spread throughout Asia until $12 \mathrm{Ma}$ (Deng et al., 2016). This is particularly important for this area, as there are no dateable volcanic sediments to provide temporal constraints (see McLaughlin, 2018). The abundance of these large ungulates indicates a potentially woodland to savannah environment capable of supporting large-bodied grazing herbivores (Nakaya et al., 1984). There are also two sizes of bovids that have been identified thus far, small and micro-, indicating an ecosystem capable of supporting a variety of adapted ungulates, potentially through niche partitioning (McLaughlin, 2018). There is also a modest assemblage of small vertebrates, notably leporids (McLaughlin, 2018). In terms of predators for this large assemblage of highly diverse herbivores, there are several smaller-bodied $(<30 \mathrm{~kg})$ hyaenids and potentially a lion-sized saber-tooth cat known for Central Asia (Zhegallo, 1961; Belyaeva and Kurdyukov, 1963; Neimyshev, 1965; Sotnikova et al., 1997; Koufos, 2016). With the addition of specimen UOMNH F70508 , one must now include the definite presence of a terrestrial medium- to large-sized $(\sim 30-100 \mathrm{~kg}$, Koufos, 2012, 2016) bone-cracking hyaena and Puma-sized $(28-65 \mathrm{~kg})$ saber-tooth cat (Salesa, 2002).

Historically, the earliest example of the clade of bone-cracking, scavenging hyenas (e.g., Palinhyaena, Belbus, Adcrocuta) are known from the early Late Miocene as the genus Adcrocuta, appearing in the Chinese locality of Lantian 19, dated to the early Bahean (Werdelin, 1996; Werdelin and Tuner 1996a, 1996b; Qiu et al., 2013; Koufos, 2016). Many of the members of the bonecracking clade are quite rare in the Miocene, at least until the extinction of dog-like hyenas at the terminal Miocene. However, Adcrocuta is almost ubiquitous in the late Miocene of Eurasia (and minimally Africa), as an integral part of the carnivore community (Werdelin and Solounias, 1990, 1991; Werdelin, 1996; de Bonis, 2005; Kovachev, 2012). Adcrocuta eximia is found in a wide variety of deposits from China to Spain, migrating from an eastern origin through Europe at the beginning of the Late Vallesian (Early Bahean, Asian Land Mammal Age, Qiu et al., 2013) (Koufos, 2016). The presence of Adcrocuta eximia in Kyrgyzstan with UOMNH F-70508 is consistent with a faunal interchange, particularly given the presence of $A$. eximia in the surrounding Kazakhstan, Tajikistan, Afghanistan, Pakistan, and Iran (Werdelin and Solounias, 1990, 1991).

\section{Evidence for Endemism at Ortok?}

As mentioned above, during the Neogene there was a considerable number of mammalian biogeographic exchanges from Asia and Africa to Europe and vice versa (Özkurt et al., 2015). Central Asia represents a key geographic route for the Eurasian part of this faunal exchange, and therefore Kyrgyzstan is optimally situated to provide insight into Eurasia's Neogene (McLaughlin, 2018).

The Kyrgyzstan Chu Formation is approximately 7.5-2.2 Ma, with the Ortok locality likely younger than $6 \mathrm{Ma}$ (McLaughlin, 2018). As mentioned previously, there have been numerous dates attributed to orogenic events in the Tien Shan of Central Asia, but all have necessarily relied upon 
proxies due to the absence of dateable volcanic material in the region. The intermediate date of 12 Ma (e.g., Makarov, 1990; Sadybakasov 1990; Abdrakhmatov et al., 2001) and Charreau et al. (2009)'s latter pulse (11-10 Ma) for orogenic initiation supports our hypothesis of a vicariance event that isolated a Paramachaerodus population (among other taxa) in this region. A P. ogygia-like ancestor could have migrated into central Asia approximately 11-10 Ma, where increased rates of tectonic uplift may have then isolated this population. This hypothesis sides well with the resultant phylogeny of this study (Figure 7) where UOMNH F-70509 displays plesiomorphic character traits at a time when only the most derived Paramachaerodus species was otherwise known to exist (P. maximiliani). Recorded geographic distributions of Paramachaerodus species span Eurasia, indicating numerous dispersal events when viewed phylogenetically. These species may have been unable to immigrate into what would have been an isolated Kyrgyzstan approximately $10 \mathrm{Ma}$ and younger, which maintained a Lazarus Paramachaerodus population endemic to the region. The remains of UOMNH F-70509 may represent early clues to an endemic Kyrgyz fauna, a relic from the initial European immigration of a $P$. ogygia-like ancestor that saw little evolutionary change (compared to contemporaneous taxa outside Kyrgyzstan) and remained unsampled until now.

Further supporting this hypothesis are additional Kyrgyz fossil fauna based on identified and described species who demonstrate a mixture of basal and derived characteristics. These include several large ungulate herbivores showing characteristics suggesting additional endemic taxa in the Ortok fauna (see McLaughlin, 2018 for details).

\section{CONCLUSIONS}

While previous researchers have briefly described fossil species and studied the geography of the Kochkor basin, this article represents one of the few detailed formal descriptions of currently existing and catalogued fauna and supports a hypothesis for endemism in the fossil fauna in Kyrgyzstan.

The presence of a morphologically consistent Adcrocuta eximia specimen at Ortok supports the assumed biogeographic boundary of Adcrocuta during the Late Miocene and also suggests evidence of a possible filter bridge between Kyrgyzstan and the surrounding areas, based on the relatively 'unchanged' morphological state of our Adcrocuta specimen. We hypothesize a filter bridge, rather than constant faunal exchange, because we also have evidence of distinct differences in other known Kyrgyz taxa (including possibly endemic Samotherium sp., Chilotherium sp., and our Paramachaerodus sp.). If there was geologic intervention - as proposed by other researchers, and we suggest with our hypothesis - then, around 11-10 Ma, selective vicariance could have begun, along with the uplift of the Tien Shan, which may have kept fauna separate and distinct as refugia species.

Paramachaerodus specimens are reported from Spain to China, spanning the European Neogene Land Mammal Zones 9-13, and Asian Land Mammal Ages Bahean-Baodean (Salesa et al., 2010; Qiu et al., 2013; Siliceo et al., 2014; Li and Spassov, 2017). These ages correspond to 9.7-4.7 Ma (Krijgsman et al., 1996; Ogg et al., 2016) and fit comfortably with the ages of the Kyrgyz sites. However, the presence of UOMNH F-70509 in this time period of Kyrgyzstan is odd given its plesiomorphic characteristics when the only other known member of this genus (at the time) was also the most derived. When compared to other taxa from Ortok, a pattern of peculiar combinations in ancestral and derived characters begins to emerge suggestive of endemism.

The value in this and future research of Kochkor Basin fossils in Kyrgyzstan is in the potential for these fossils to add and revise regional pictures of orogenic events of the Central Asian Miocene landscape, biodiversity, and endemism, which may otherwise be overlooked.

\section{ACKNOWLEDGEMENTS}

The authors would like to thank the following individuals and institutions for access and assistance with specimens during the course of this research: K. Abdrakhmatov from the Kyrgyz Institute of Seismology; J. Galkin of the American Museum of Natural History; and A. Ferguson of the Chicago Field Museum. Thanks also to S. Dueppen for his part in the discussions about general hyena biodiversity, J. McLaughlin for the original discovery of the fossil, and H. Flora and L. Finkelman for their assistance reviewing the initial draft manuscript and figures. Thanks to R. Weldon for sharing his extensive knowledge of Kyrgyz geology and help in the field. Thanks to L. Werdelin and anonymous reviewers for their comments and suggestions on revising this work. Finally, this work was supported by the 2017 American Alpine Research Grant and NSF grant (DEB-1256897). The authors have no conflicts of interest to declare. 


\section{REFERENCES}

Abdrakhmatov, K., Weldon, R.J., Thompson, S.C., Burbank, D.W., Rubin, C., Miller, M., and Molnar, P. 2001. Onset, style and current rate of shortening in the central Tien Shan, Kyrgyz Republic. Russian Geology and Geophysics, 42:1585-1609.

Averianov, A. and Godinot, M. 1998. A report on the Eocene Andarak mammal fauna of Kyrgyzstan. Bulletin of Carnegie Museum of Natural History, 34:210-219.

Averianov, A. and Godinot, M. 2005. Ceratomorphs (Mammalia, Perissodactyla) from the early Eocene Andarak 2 locality in Kyrgyzstan. Geodiversitas, 27:221-237.

Barrett, P.Z. 2016. Taxonomic and systematic revisions to the North American Nimravidae (Mammalia, Carnivora). PeerJ, 4:e1658. https://doi.org/10.7717/peerj.1658

Bell, M.A. and Lloyd, G.T. 2014. Strap: Stratigraphic Tree Analysis for Palaeontology. R package version 1.4. https://CRAN.R-project.org/package=strap

Belyaeva, E.I. 1962. First record of a tapiromorph in the Eocene of Middle Asia. Byuleten' Moskovskogo Obschestva Ispytatelei Prirody. Otdel Geologicheskii, 37:142-145.

Belyaeva, E.I. and Kurdyukov, K.V. 1963. About new finds of fossil mammals in North Kyrgyzstan. Bulletin KICHP, 28:76-83. (In Russian)

Bryant, H.N. 1988. The anatomy, phylogenetic relationships and systematics of the Nimravidae (Mammalia: Carnivora). Unpublished PhD Thesis, University of Toronto, Toronto, Canada.

Bryant, H.N. 1991. Phylogenetic relationships and systematics of the Nimravidae (Carnivora). Journal of Mammalogy, 72:56-78. https://doi.org/10.2307/1381980

Caves, J.K., Bayshashov, B.U., Zhamangara, A., Ritch, A.J., Ibarra, D.E., Sjostrom, D.J., Mix, H.T., Winnick, M.J., and Chamberlain, C.P. 2017. Late Miocene uplift of the Tian Shan and Altai and reorganization of Central Asia climate. GSA Today, 27:20-26. https://doi.org/ 10.1130/gsatg305a.1

Charreau, J., Chen, Y., Gilder, S., Barrier, L., Dominguez, S., Augier, R., Sen, S., Avouac, J.P., Gallaud, A., Graveleau, F., and Wang, Q. 2009. Neogene uplift of the Tian Shan Mountains observed in the magnetic record of the Jingou River section (northwest China). Tectonics, 28:1-22. https://doi.org/10.1029/2007tc002137

Christiansen, P. 2013. Phylogeny of the sabertoothed felids (Carnivora: Felidae: Machairodontinae). Cladistics, 29:543-559. https://doi.org/10.7934/p681

de Bonis, L. 2005. Carnivora (Mammalia) from the late Miocene of Akkasdagi, Turkey. Geodiversitas, 27:567-589.

Deng, T., Wang, H., Wang, X., Li, Q., and Tseng, Z. J. 2016. The late Miocene Hipparion (Equidae, Perissodactyla) fossils from Baogeda Ula, Inner Mongolia, China. Historical Biology, 28:53-68. https://doi.org/10.1080/08912963.2015.1020425

Dmitrieva, E.L. and Nesmejanov, S.A. 1982. Mammals and stratigraphy of tertiary continental deposits in South-Eastern Central Asia, catalog of local. Trudy Paleontologicheskogo Instituta Akademiya Nauk SSSR, 193:87-113.

Erfurt, J., Averianov, A.O., Buchantschenko, J., and Fortuna, A.B. 1999. Rediscovery of the Eocene mammal site Toru Ajgyr (Kyrgyzstan). Hallesches Jahrbuch Geowissenschaften B21:107-127.

Fischer von Waldheim, G. 1817. Adversaria zoologica. Mémoires de la Société Impériale des Naturalistes de Moscou, 5:357-428.

Gill, T. 1872. Arrangement of the families of mammals with analytical tables. Smithsonian Micellaneous Collections, 11:1-98. https://doi.org/10.5962/bhl.title.14607

Ghaffar, A., Akhtar, M., Butt, M.J., Khan, M.A., and Ikram, T. 2011. Late Miocene hyaenids from the middle Siwaliks of Pakistan. Pakistan Journal of Zoology, 43:855-862.

Goloboff, P.A. and Catalano, S.A. 2016. TNT version 1.5, including a full implementation of phylogenetic morphometrics. Cladistics, 32:221-238. https://doi.org/10.1111/cla.12160

Gray, J.E. 1821. On the natural arrangement of vertebrate animals. The London Medical Repository Monthly Journal and Review, 15:296-310.

Howell, F.C. and Petter, G. 1980. The Pachycrocuta and Hyaena lineages (Plio-Pleistocene and extant species of the Hyaenidae). Their relationships with Miocene Ictitheres: Palhyaena and Hyaenictitherium. Geobios, 13:579-623. https://doi.org/10.1016/s0016-6995(80)80004-0 
Howell, F.C. and Petter, G. 1985. Comparative observations on some middle and upper Miocene genera: Percrocuta Kretzoi, Allohyaena Kretzoi, Adcrocuta Kretzoi. Geobios, 18:419-491. https://doi.org/10.1016/s0016-6995(85)80001-2

Kaup, J.J. 1829. Über Hyaena, Uromastix, Basiliscus, Corythaeolus, Acontias. Isis, 21:11441150. (In German)

Kaup, J.J. 1832. Vier neue arten urweltlicher raubthiere welche im zoologischen Museum zu Darmstadt aufbewart warden. Archiv für Mineralogie, 5:150-158. (In German)

Koufos, G.D. 2012. New material of Carnivora (Mammalia) from the Late Miocene of Axios Valley, Macedonia, Greece. Comptes Rendus Palevol, 11:49-64. https://doi.org/10.1016/ j.crpv.2011.09.004

Koufos, G.D. 2016. Carnivora. Geobios, 49:53-67. https://doi.org/10.1016/j.geobios.2016.01.013

Kovachev, D. 2012. A complete skeleton of Adcrocuta eximia (Roth and Wagner, 1854) from the Upper Maeotian (Turolian) of Hadzhidimovo, SW Bulgaria. Geologica Balkanica, 41:77-95.

Kretzoi, N. 1929. Materialien zur phylogenetischen klassifikation der Aeluroïdeen. X Congres International de Zoologie, Budapest 1927, 2:1293-1355. (In German)

Kretzoi, M. 1938. Die raubtiere von gombaszög nebst einer übersicht der gesamt-fauna (ein beitrag zur stratigraphie des altquartaers). Annals Museum Naturalis Hungarici, 31:89-157. (In German)

Krijgsman, W., Garcés, M., Langereis, C.G., Daams, R., van Dam, J., van der Meulen, A.J., Agustí, J., and Cabrera, L. 1996. A new chronology for the middle to late Miocene continental record in Spain. Earth and Planetary Science Letters, 142:367-380. https://doi.org/10.1016/ 0012-821x(96)00109-4

Li, Y. and Spassov, N. 2017. A new species of Paramachaerodus (Mammalia, Carnivora, Felidae) from the late Miocene of China and Bulgaria, and revision of Promegantereon Kretzoi, 1938 and Paramachaerodus Pilgrim, 1913. Paläontologische Zeitschrift, 91:409-426. https://doi.org/10.1007/s12542-017-0371-7

Macaulay, E.A., Sobel, E.R., Mikolaichuk, A., Wack, M., Gilder, S.A., Mulch, A., Fortuna, A. B., Hynek, S., and Apayarov, F. 2016. The sedimentary record of the Issyk Kul basin, Kyrgyzstan: climatic and tectonic inferences. Basin Research, 28:57-80. https://doi.org/ 10.1111/bre.12098

Makarov, V.I. 1990. Late Cenozoic Orogens, Their Structure and Geodynamics. Unpublished Scientific Report for Doctor of Geological and Minerological Sciences, Geological Institute Russian Academy of Science, Moscow, Russia. (In Russian)

McKenna, M.C. and Bell, S.K. 1997. Classification of Mammals above the Species Level. Columbia University Press, New York.

McLaughlin, W.N.F. 2018. Landscape and Biotic Evolution of the Kochkor Basin, Kyrgyzstan. Unpublished PhD Thesis, University of Oregon, Eugene, Oregon, USA.

Mikolaichuk, A.V., Apayarov, F.Kh., Buchroithner, M.F., Chernavskaja, Z.I., Skrinnik, L.I., Ghes, M.D., Neyevin, A.V., and Charimov, T.A. 2008. Geological Map of Khan Tengri Massif, Explanatory Note. ISTC Project No. \#KR-920. ISTC, Bishkek, Kyrgyzstan.

Ministry of Environmental Protection. 1998. Kyrgyz Republic Biodiversity Strategy and Action Plan, Strategies. Ministry of Environmental Protection, Bishkek.

Nakaya, H., Pickford, M., Nakano, Y., and Ishida, H. 1984. The Late Miocene large mammal fauna from the Namurungule Formation, Samburu Hills, northern Kenya. African Study Monographs, Supplemental, 2:87-131.

Neimyshev, M.V. 1965. New Data in Tien Shan Stratigraphy. Unpublished PhD Thesis, Frunze Polytechnic Institute, Bishkek, Kyrgyzstan. (In Russian)

Ogg, J.G., Ogg, G., and Gradstein, F.M. 2016. A Concise Geologic Time Scale 2016. Elsevier, Amsterdam.

Özkurt, Ş.Ö., Güleç, E., and Erkman, A.C. 2015. Carnivores from the Late Miocene locality of Hayranlı (Hayranlı, Sivas, Turkey). Turkish Journal of Zoology, 39:842-867. https://doi.org/ 10.3906/zoo-1407-38

Paijmans, J.L.A., Barnett, R., Gilbert, M.T.P., Zepeda-Mendoza, M.L., Reumer, J.W.F., de Vos, J., Zazula, G., Nagel, D., Baryshnikov, G.F., Leonard, J.A., Rohland, N., Westbury, M.V., Barlow, A., and Hofreiter, M. 2017. Evolutionary history of saber-toothed cats based on ancient mitogenomics. Current Biology, 27:3330-3336. https://doi.org/10.1016/j.cub.2017.09.033

Paulson, K. 2013. Generation of Structural Relief by Fault Propagation Folding, Tien Shan, Kyrgyzstan. Unpublished Master's Thesis, University of Oregon, Eugene, Oregon, USA. 
Pilgrim, G.E. 1913. The correlation of the Siwaliks with mammal horizons of Europe. Records of the Geological Survey of India, 43:264-326.

Qiu, Z.-X., Qiu, Z.-D., Deng, T., Li, C.-K., Zhang, Z.-Q., Wang, B.-Y., and Wang, X.-M. 2013. Neogene land mammal stages/ages of China: Toward the goal to establish an Asian land mammal stage/age scheme, p. 29-90. In Wang, X.-M., Flynn, L.J., and Fortelius, M. (eds.), Fossil Mammals of Asia: Neogene Biostratigraphy and Chronology. Columbia University Press, New York.

R Core Team. 2019. R: A language and environment for statistical computing. R Foundation for Statistical Computing, Vienna, Austria. URL https://www.R-project.org/.

Roth, J. and Wagner, A. 1854. Die fossilen Knochenü berreste von Pikermi in Griechen-land. Abhandlungen Bayerische Akademie Wissenschaften. München Verlag der k. Akademic, München. (In German)

Sadybakasov, I. 1990. Neotectonics of High Asia. Nauka, Moscow.

Salesa, M.J. 2002. Estudio Anatómico, Biomecánico, Paleoecológico y Filogenético de Paramachairodus ogygia (Kaup, 1832) Pilgrim, 1913 (Felidae, Machairodontinae) del yacimiento vallesiense (Mioceno superior) de Batallones-I (Torrejón de Velasco, Madrid). Unpublished PhD thesis, Departamento de Biología Animal I, Facultad de Ciencias Biológicas, Universidad Complutense de Madrid, Madrid. (In Spanish)

Salesa, M.J., Anton, M., Turner, A., Alcala, L., Montoya, P., and Morales, J. 2010. Systematic revision of the Late Miocene sabre-toothed felid Paramachaerodus in Spain. Palaeontology, 53:1369-1391. https://doi.org/10.1111/j.1475-4983.2010.01013.x

Semenov, Y. 2008. Taxonomical reappraisal of "ictitheres" (Mammalia, Carnivora) from the Late Miocene of Kenya. Comptes Rendus Palevol, 7:529-539. https://doi.org/10.1016/ j.crpv.2008.09.012

Siliceo, G., Salesa, M.J., Antón, M., Monescillo, M.F.G., and Morales, J. 2014. Promegantereon ogygia (Felidae, Machairodontinae, Smilodontini) from the Vallesian (late Miocene, MN 10) of Spain: morphological and functional differences in two noncontemporary populations. Journal of Vertebrate Paleontology, 34:407-418. https://doi.org/10.1080/02724634.2013.812099

Sobel, E.R. and Dumitru, T.A. 1997. Thrusting and exhumation around the margins of the western Tarim Basin during the India-Asia collision. Journal of Geophysical Research, 102:5043-5063. https://doi.org/10.1029/96jb03267

Solé, F. and Ladevèze, S. 2017. Evolution of the hypercarnivorous dentition in mammals (Metatheria, Eutheria) and its bearing on the development of tribosphenic molars. Evolution and Development, 19:56-68. https://doi.org/10.1111/ede.12219

Sotnikova, M.V., Dodonov, A.E., and Pen'kov, A.V. 1997. Upper Cenozoic bio-magnetic stratigraphy of Central Asian mammalian localities. Palaeogeography, Palaeoclimatology, Palaeoecology, 133:243-258. https://doi.org/10.1016/s0031-0182(97)00078-3

Spassov, N. and Geraads, D. 2015. A new felid from the Late Miocene of the Balkans and the contents of the genus Metailurus Zdansky, 1924 (Carnivora, Felidae). Journal of Mammal Evolution, 22:45-56. https://doi.org/10.1007/s10914-014-9266-5

Tarasov, S.A. 1970. Cenozoic Geology and Neotectonics of the Tien Shan. Ilim, Frunze (Bishkek). (In Russian)

Tseng, Z.J. 2011. Variation and implications of intra-dentition hunter-schreger band pattern in fossil hyaenids and canids (Carnivora, Mammalia). Journal of Vertebrate Paleontology, 31:1163-1167. https://doi.org/10.1080/02724634.2011.602161

Turner, A., Antón, M., and Werdelin, L. 2008. Taxonomy and evolutionary patterns in the fossil Hyaenidae of Europe. Geobios, 41:677-687. https://doi.org/10.1016/j.geobios.2008.01.001

Vangengeim, E.A., Pevzner, M.L., and Gabunija, L.K. 1989. Correlation of the late Cenozoic deposits of Palearctic (based on mammals). Trudy Geologicheskogo Instituta Akademiya Nauk SSSR, 431:220-227.

von den Driesch, A. 1976. A Guide to the Measurement of Animal Bones from Archaeological Sites: As Developed by the Institut Für Palaeoanatomie, Domestikationsforschung und Geschichte der Tiermedizin of the University of Munich. Peabody Museum of Archaeology and Ethnology, Harvard University, Cambridge, Massachusetts.

Wallace, S.C. and Hulbert, R.C. 2013. A new Machairodont from the Palmetto fauna (Early Pliocene) of Florida, with comments on the origin of the Smilodontini (Mammalia, Carnivora, Felidae). PLoS ONE, 8:56173. https://doi.org/10.1371/journal.pone.0056173

Werdelin, L. 1996. Community-wide character displacement in Miocene hyenas. Lethaia, 29:97103. https://doi.org/10.1111/j.1502-3931.1996.tb01843.x 
Werdelin, L. and Kurtén, B. 1999. Allohyaena (Mammalia: Carnivora): giant Hyaenid from the Late Miocene of Hungary. Zoological Journal of the Linnean Society, 126:319-334. https:// doi.org/10.1111/j.1096-3642.1999.tb01374.x

Werdelin, L. and Solounias, N. 1990. Studies of fossil hyaenids: the genus Adcrocuta Kretzoi and the interrelationships of some hyaenid taxa. Zoological Journal of the Linnaean Society, 98:363-386. https://doi.org/10.1111/j.1096-3642.1990.tb01206.x

Werdelin, L. and Solounias, N. 1991. The Hyaenidae: taxonomy, systematics and evolution. Fossils and Strata, 30:1-104.

Werdelin, L. and Turner, A. 1996a. The fossil Hyaenidae of Africa: present status, p.637-659. In Stewart, K.M. and Seymour, K.L. (eds.), Palaeoecology and Paleoenvironments of Late Cenozoic Mammals. University of Toronto Press, Toronto.

Werdelin, L. and Turner A. 1996b. Turnover in the guild of larger carnivores in Eurasia across the Miocene-Pliocene boundary. Acta Zoologica Cracoviensia, 39:585-592.

Werdelin, L., Yamaguchi, N., Johnson, W.E., and O'Brien, S.J. 2010. Phylogeny and evolution of cats (Felidae), p.59-82. In Macdonald, D.W. and Loveridge, A.J. (eds.), Biology and Conservation of Wild Felids. Oxford University Press, New York.

Zdansky, O. 1924. Jungtertiäre Carnivoren Chinas. Palaeontologica Sinica, 2:1-149. (In German) https://doi.org/10.1086/623252

Zhang, Z. 2005. New materials of Dinocrocuta (Percrocutidae, Carnivora) from Lantian, Shaanxi Province, China, and remarks on Chinese Late Miocene biochronology. Geobios, 38:685689. https://doi.org/10.1016/j.geobios.2004.03.005

Zhegallo, V.I. 1961. Location study of the Ortok fauna (Kirghiz copy). Bulletin MOIP, 3:119-120. (In Russian) 


\section{APPENDIX 1.}

Phylogenetic character matrix scoring UOMNH F-70509, featuring our additional character (19 describes the reduction of the first upper molar) and the character matrix of Li and Spassov (2017). This matrix was analysed under the parsimony optimality criterion in TNT 1.5 (Goloboff and Catalano, 2016) via implicit enumeration with unordered characters and the taxon Proailurus lemanensis as the outgroup.

Character Matrix: .nex file

\#NEXUS

\section{BEGIN DATA;}

DIMENSIONS NTAX=6 NCHAR=19;

FORMAT DATATYPE = STANDARD RESPECTCASE GAP = - MISSING = ? SYMBOLS = " 0123 4";

\section{CHARLABELS}

Nasal_bones_shape Shape_of_upper_canine_crown Upper_canine_crenulations Orientation_of_PM3_and_PM4. Mesial_cusp_of_PM3 'PM-̄isto-lingual basal expansion of crown' 'PM3, mesio-distal elongation of crown' 'Relative size PM4-PM3' Place_of_PM4_protocone Buccal_border_of_PM4 Protocone_of_PM4 PM4_ectostyle M1_crown Mandibular_symphysis_outline pm2 'pm4 mesio-buccal basal expansion in the crown' m1_talonid. Sagittal_crest M1_roots ;

\section{MATRIX}

Proailurus_lemanensis ?000000000000000000

Promegantereon_ogygia 0100100000000100101

Paramachaerodus_transasiaticus 111110110111021(0 1)211

Paramachaerodus_orientalis 21210111122212214?(1 2)

Paramachaerodus_maximiliani 2120?0111222122?31(1 2)

'UOMNH F-70509' ?11?????????0?????0

END; 


\section{APPENDIX 2.}

Comparative serration density per millimeter as counted on the canines of Nimravidae and Machairodontinae specimens from assorted museum specimens. Institutional abbreviations: AMNH, American Museum of Natural History, Division of Paleontology, New York, New York, USA; F:AM, American Museum of Natural History, Frick Collection, New York, New York, USA; UF, Florida Museum of Natural History, University of Florida, Gainesville, Florida, USA; LACMHC, Los Angeles County Museum, George C. Page Museum (Hancock Collection), Los Angeles, California, USA.

\begin{tabular}{|c|c|c|}
\hline $\begin{array}{c}\text { Specimen Numberl } \\
\text { Ref. }\end{array}$ & Taxon & $\begin{array}{c}\text { Serration density } \\
(\# / \mathrm{mm})\end{array}$ \\
\hline \multicolumn{3}{|l|}{ Nimravidae } \\
\hline AMNH 79999 & Barbourofelis morrisi & 4.1 \\
\hline F:AM 25204 & Barbourofelis morrisi & 4.3 \\
\hline F:AM 69359 & Barbourofelis morrisi & 3.7 \\
\hline Bryant (1988) & Barbourofelis loveorum & 3.9 \\
\hline AMNH 108193 & Barbourofelis fricki & 4.0 \\
\hline F:AM 61983 & Barbourofelis fricki & 3.7 \\
\hline F:AM 61856 & Albanosmilus whitfordi & 4.1 \\
\hline F:AM 61849 & Albanosmilus whitfordi & 4.1 \\
\hline \multicolumn{3}{|l|}{ Machairodontinae } \\
\hline AMNH 95297 & Homotherium ischyrus & 1.8 \\
\hline F:AM 50461 & Homotherium latidens & 2.1 \\
\hline F:AM 50469 & Homotherium latidens & 2.2 \\
\hline F:AM 50445 & Dinofelis diastemata & 2.1 \\
\hline F:AM 50478 & Amphimachairodus giganteus & 1.9 \\
\hline F:AM 104044 & Machairodus catocopis & 2.3 \\
\hline F:AM 69263 & Machairodus coloradoensis & 1.8 \\
\hline UF 60000 & Xenosmilus hodsonae & 1.1 \\
\hline LACMHC A-3708 & Smilodon fatalis & 2.6 \\
\hline
\end{tabular}

